第3困nーアルキルフェニルケトンの反度率 ル基の長いるのほ

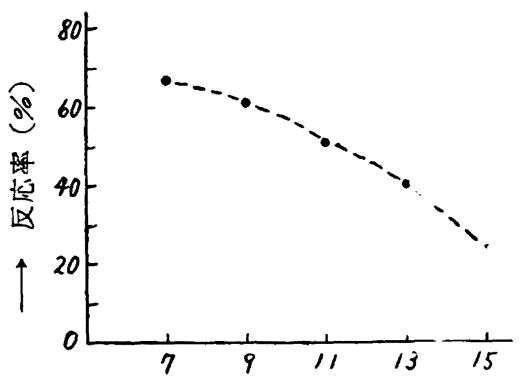

$\longrightarrow$ ケトン $\mathrm{R}^{\prime}$ 炭素数 傾向が見られる。 この原因を明かに するため緩慢な酸 化に拈ける反応中 間体を検討した。
ど酸化率は低くな $\eta$, 前述の強酸化 の場合と全く逆な

\section{3. 反応中間体}

の検封 ケトン

$100 \mathrm{~g}$ を $9 \mathrm{~N}$ 硝酸を用い, $90^{\circ} \mathrm{C} て ゙ 1$ 時間反応させ, 生成物を熱 湯で洗浄して硝酸拉よび安息香酸を除去したのち, さらに不ヶン 化物を除き, 可ヶン化物のベンゼン溶液にアルコール性カセイカ リを加えると黄色リン片状の結晶がえられた。これは前記の 150 ${ }^{\circ} \mathrm{C}$ で酸化した場合にはえられなかったるので, カリ塩の結晶と 考えられるが, その絬晶性よりみて脂肪酸のカリ塩とは考えられ ない。この結晶の収量および窒素分析值, カリ塩を分解せるるの の沸点を第 9 表に示す。

\begin{tabular}{|c|c|c|c|c|}
\hline 試料タトン $\mathrm{R}$ & $\begin{array}{r}\text { (1) 塩 } \\
\mathrm{C}_{\boldsymbol{\theta}}\end{array}$ & $\begin{aligned} \text { び } \\
\mathrm{C}_{11}\end{aligned}$ & 解物 & $\mathrm{C}_{16}$ \\
\hline 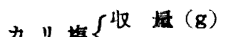 & 32 & 27 & 29 & 34 \\
\hline 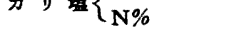 & 11.25 & - & 5.12 & 9.56 \\
\hline 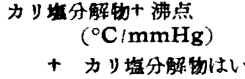 & $115 / 2$ & $144 / 4$ & $195 / 4$ & $177 \sim 179 / 5$ \\
\hline
\end{tabular}

第 9 表から明らかなよ 5 に, 窒素含有量および沸点のいずれよ り見ても単にアルキル基の長さによるたけの差異とは考えられな い值を示している。カリ塩は分解して蒸留する際に, 熱に対して 不安定で，熱分解重合等をおこし，その正確な性状は認め難いの で上記沸点もその主留分と考えられるものを示した。nーペンタデ シルフェニルケトンの酸化中間体カリ塩を強塩酸と加熱すれば, 安息香酸の生成が確かめられ，中間体はベンゼン核を有するもの
と考えられる。赤外吸収スペクトル解析によれば, いずれすよく 似た吸収スペクトルを示し，一連の関連性が認められる。すなる ち, カルボニル基, カルボキシル基に相当する吸収は認められ ず, $6.25 \mu, 6.45 \mu, 7.47 \mu, 13.3 \mu, 14.3 \mu$ に吸収が認めら れ，これらはモノ置換ベンゼン，ニトロ基の吸収に相当すると考 えられる。このことよりこれらのカリ塩はカルボン酸のカリ塩で はなく, ニトロ基のカリ塩と考えられるが, その構造については さらに詳細な研究を必要とする。したがってかよ5な中間生成焉 が強酸化の場合にす生じるかどうか，強酸化と緩慢酸化とは同一 の反応経過をとるかどうかについてはさらに検討を要する。

\section{III. 総 括}

1. n-アルキルフェニルケトンの銅クロム触媒による接触㬓元 法では, ケトンよりカルビノールおよびアルキルベンゼンへの通 元はアルキル基の炭素数が大きいほど容易であり，その際いずれ の場合にも反応副生物として，反応中間体であるオレフィンの 2 分子重合体の水素化物と考えられるるのが見出された。

2. 本還元法はアルキル基の炭素数 11 以上のものについては, 他の還元法にくらべて簡単な操作で短時間に好収率で多量の遑元 を行いうるものとして有利である。

3. ケトンの硝酸酸化により比較的容易に奇数炭素数の脂肪酸 がえられ, 反応温度 $150^{\circ} \mathrm{C}$, 硝酸濃度 $13.44 \mathrm{~N}$ の条件ではアル キル基の長いほど酸化収率は高いことが認められたが，反応温度 $90^{\circ} \mathrm{C}$, 硝酸濃度 $9 \mathrm{~N}$ の条件ではヶトンの反応率はそれと逆の傾 向を示し,この場合にはニト口基を含むと考えられる構造不明の 副生物が生じていることが認められた。

（昭和 30 年 4 月 1 日，日化第 8 年会，昭和 31 年 4 月 4 日， 日化第 9 年会講演)

終りに原料脂肪酸の一部を提供して下さった日本油脂株式会社 佃工場, 赤外吸収スペクトル解析に御協力下さった大阪市立大学 理工学部藤野明氏に対して謝意を表します。

\title{
抗酸化剤としてのピロカテコール誘導体†
}

(昭 和 31 年 10 月 29 日受 理)

松田 住 雄・山田 冨貴子*

著者らはさきに，ピロカテコールと脂肪族二塩基酸により $\omega$,

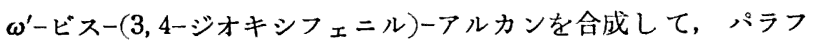
インワックスに対する抗酸化性について検討を行った結果, ND GA よりはるかにすぐれた抗酸化性をみとめた1)。しかし，この 合成の各反応過程はきわめて収率が悪い。よって良好な収率です ぐれた抗酸化性を有する化合物をえようとして，二塩基酸として テレフタル酸, イソフタル酸のような芳香族二塩基酸と, ピロカ テコール，ヒドロキノンとよりビスー(オキシベンジル)ーベンゼン およびその類似化合物の合成をこころみ, その抗酸化性と化学構 造の関係について若干の知見をうることができた。

†本報告を「添加剂に関する研究（第1 報)」とする。

* 大阪大学工学部応用化学教室: 大阪市都島区.

1) 山田, 松田, 工化 59, 59 (1956).
2 価フェノールのジメチルェーテルと酸クロリドとを無水塩化 アルミニウムを触媒とするフリーデル・クラフッ反応により，モ ノまたはジヶトンとし, ウォルフキッスナー法, クレメンゼン法 により還元を行い, のち臭化水素酸によって脱メチルを行って目 的物をえた。

ベラトロールとテレフタル酸ジクロリドを無水塩化アルミニウ

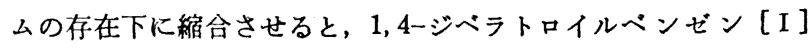
扣よび，4一ベラトロイル安息香酸 [II] を生成する。

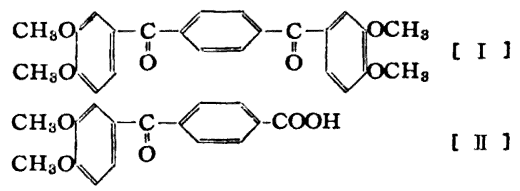

[I ] および［II] はそれぞれ 2,4-ジニトロフェニルヒドラジ 
ンを生成する。

［I］拉よび [II] を過マンガン酸カリで酸化すればテレフタ ル酸とベラトロールがえられ，したがってベラトロールと酸クロ リドの反応位置は酸化のよ5な化学的方法によってはこれを決定 ナることができない。しかし著者らはすでに $\omega, \omega^{\prime}$-ジベラトロイ ルーアルカン類の酸化成績体としてベラトルム酸をえており リーデル・クラフッ反応にお活るベラトロール核の反応位置は主 として $p$-位置であることを確認しているので, この場合反応位 置は主として p-位置であると推定した。

つぎに, ジヶトン扰びヶト酸をウォルフ・キッスナー法によ り還元して 1,4-ジベラトリルベンゼン［III］，および 4-ベラト リル安息香酸 $[\mathrm{V}]$ をえた。

還元物を $48 \%$ 具化水素酸と酶酸により脱メチルを行い，1，4ビス（3，4-ジオキシベンジル)ーベンゼン [N] 拈よび，4-(3,4ジオキシベンジル)-安息香酸（U）をえた。

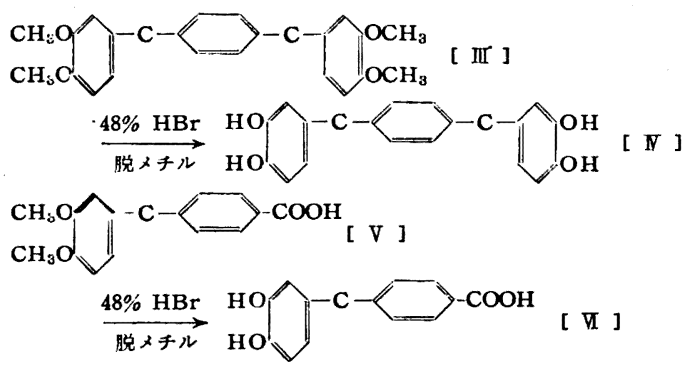

また［I］を同様に脱メチルして 1,4-ビス（3,4-ジオキシべ ンゾイル)ーベンゼン［UI] をえた。[VII] は 2,4-ジニトロフェニ ルヒドラジンを生成する。

[I] $\underset{\text { 脱メチル }}{\stackrel{48 \% \mathrm{HBr}}{\longrightarrow}}$

ヒドロキノンのジメチルエーテルとテレフタル酸ジクロリドを フリーデル・クラフッ反応で縮合すれば, 1,4-ビス (2,5-ジメト キシベンゾイル)-ベンゼン [UII] と 4-(2,5-ジメトキシベンゾイ ル)安息香酸 $[\mathrm{X}]$ がえられた。これらは 2,4-ジニトロフェニ ルヒドラゾンを生成する。ウォルフ・キッスナー法によって還元 すればそれぞれ 1,4-ビス（2,5-ジメトキシベンジル)-ベンゼ， [X] 怙よび，4-(2,5-ジメトキシベンジル)-安息香酸 [X] がえ られ，さらにこれらを脱メチルすれば，1,4-ビス (2,5-ジオキシ ベンジル)ーベンゼン [XII] がえられた。しかし [XI] を脱メチル するときわめて不安定で, たたちに黒紫色に変化して, 再結晶 法, 活性炭処理をくりかえする, 脱メチルした安息香酸誘導体を 精彆しえず,したがってその定数は測定することができなかった。

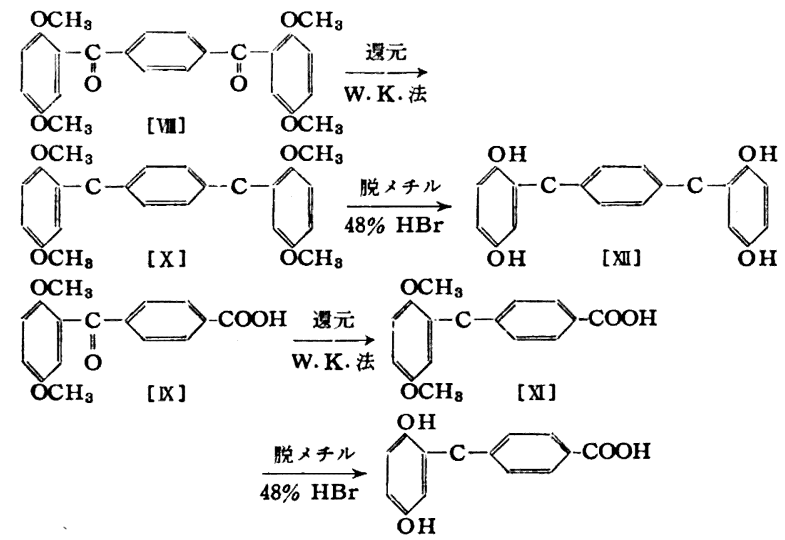

[N] と [XII] は対称性の化学溝造を有する。これに対して非対 称構造を有するもので, 一方にピロカテコール核, 他方にヒドロ キノン核をむつテレフタル酸誘導体を合成した。すなわち，4(2,5-ジメトキシベンジル)-安息香酸 $[\mathrm{X}]$ を五塩化リンで酸ク ロリドとし，ベラトロールとフリーデル・クラフッ反応を行 5 と, 1-(ベラトロイル)-1-(2,5 ジメトキシーベンジル)-ベンゼン [XIII] をえる。

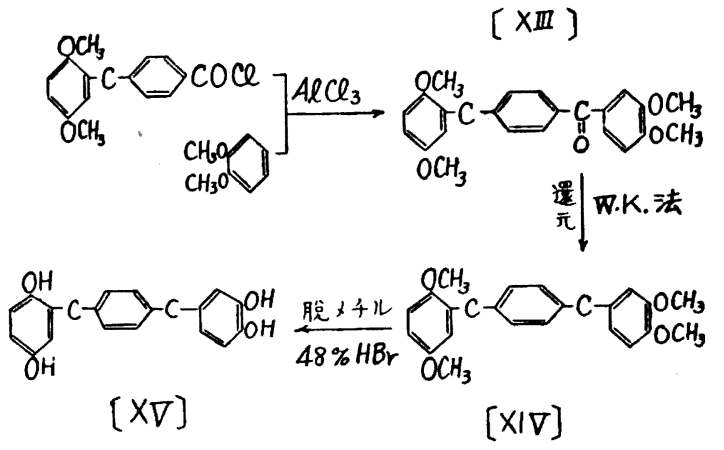

このモノケトン [XIII] をウォルフ・キッスナー法により運元 すれば, 1-(ベラトリル)-4-(2,5-ジメトキシベンジル)-ベンゼン [XIV]をろる。さらに [XIV] を脱メチルすれば, 1-(3,4-ジオ キシベンジル)-4-(2,5-ジオキシベンジル)-ベンゼン $[\mathrm{XV}]$ がえ られた。

レゾルシンジメチルエーテルとテレフタル酸ジクロリドとのフ リーデル・クラフッ反応に执いては, 上述のピロカテュールある いは，ヒドロキノンの場合とは相違した複雑な反応性を示した。 すなわち，この反応においてえられたケトンはベンゼンとアルコ ールによる再結晶を数回くり返しても融点範囲は広く, 単一物よ りなるるのとは考えられない。フリーデル・クラフッ反応の条 件を変えることにより, 少量の融点範囲のせまい, 純粋と思われ る物質を単離することができた。融点, 元素分析等, その性状よ りして 1,4-ビスー(ジメトオキシベンゾイル)-ベンゼン [XVI] と みとめられる。生成結晶の融点範囲の広いことはレゾルシンジメ チルエーテルに対する酸クロリドの反応位置が， 1 カ所のみにと どまらないことによるものと考えられる。副反応生成物としてヶ<smiles>COc1ccc(C(=O)C2CCC(C(=O)c3ccc(Cl)cc3)CC2)cc1</smiles><smiles>CC(C)(C)C1CC2CCC1C2C(=O)c1ccc(C(=O)O)cc1</smiles>
ト酸 $[\mathrm{XVII}]$ がえられた。 ジヶトンおよびケト酸はそ れぞれ，2,4-ジニトロフェ ニルヒドラゾンを生成す る。

[XVII] イソフタル酸ジクロリド とベラトロールのフリーデ ル・クラフッ反応に拁いては上述の諸例と同様に, 1,3-ジベラト ロイルベンゼン $[\mathrm{XVIII}]$ 扰よび,3-ベラトロイル安息香酸 $[\mathrm{XIX}]$ がえられ，これらはいずれる 2,4-ジニトロフェニルヒドラゾン を生成する。ウォルフ・キッスナー法により還元すれば, 1,3-ジ ベラトリルベンゼン $[X X]$ 扣よび,3-ベラトリル安息香酸 $[X X I]$ をうる。 $[\mathrm{XX}],[\mathrm{XXI}]$ を脱メチルして 1,3-ビスー(3,4-ジオキ シベンジル)-ベンゼン [XXII] および3-(3,4-ジオキシベンジル) 一安息香酸 $[\mathrm{XXIII]} \mathrm{をえた。また}[\mathrm{XVIII}]$ を脱メチルすれば， 1,3-ビス-(3,4-ジオキシベンゾイル)-ベンゼン [XXIV] をうる。

ヒドロキノンジメチルエーテルとイソフタル酸ジクロリドとの フリーデル・クラフッ反応に怙いては, 多量の粘着性樹脂状物質 
$\mathrm{CH}_{\circ} \mathrm{O}$ 整 W.K. 法 $\mathrm{CH}_{3} \mathrm{O}$ ${ }_{\mathrm{HO}}^{\mathrm{COXII}]}$<smiles>COC1CC2CCC(C1)C(C(=O)O)C(C(=O)O)CC2</smiles>

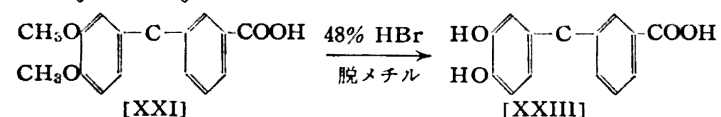
[XXI] [XXIII]

をともない，1，3-ビスー(2,5-ジメトキシベンゾイル)ーベンゼン [XXV] は少量分離されたのみできわめて収率悪く, したがって 還元反応を行らことができなかった。ジヶトン [XXV] は 2,4ジニトロフェニルヒドラゾンを生成する。ケト酸として 3- $(2,5-$ ジメトキシベンゾイル)-安息香酸 [XXVI] をえたが，これは 2 , 4-ジニトロフェニルヒドラゾンを生成する。

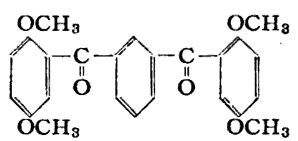
[XXV]

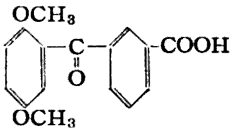

[XXVI]
フタル酸ジクロリドとベラトロールとをフリーデル・クラフッ 反応により縮合させると，1，2-ジベラトロイルベンゼン [XXVII]

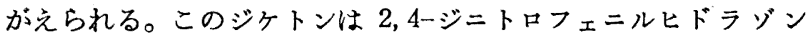
を生成しない。またクレメンゼ ン法, ウォルフ・キッスナー法 によるも還元は不可能であっ た。

p-tert-ブチルベラトロール とテレフタル酸ジクロリドとの

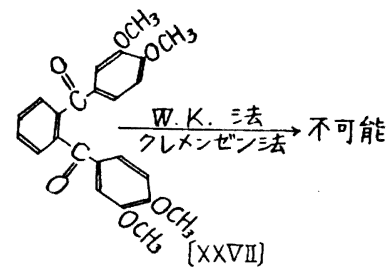
フリーデル・クラフッ反応によ

.り，1４４-ビス-(2,3-ジメトキシ-5-tert-ブチルペンゾイル)-ベン ゼンの合成をこころみたが，塩化アルミニウムを触媒とするフリ ーデル・クラフッ反応に执いては，tert-ブチル甚は離脱して，兄 られたジヶトンは融点, $\mathrm{OCH}_{3} \%$ は，[I］に等しく，［］］と混 融しても融点の低下を示さず同一物質なることをたしかめた。

以上 $[\mathrm{I}] \sim[\mathrm{XXVII}]$ および，2,4-ジニトロフェニルヒドラゾ ン誘導体は, 著者らの入手したかぎりの文献においては未記載の 新化合物である。

4-アルキルピロカテコールは抗酸化剤としての利用面より Morris $^{2)}$, Bickoff ${ }^{3)}$, Miller ${ }^{4)}$, Haworth ${ }^{5)}$, 田村6)らによって報告 されており，アルキル基の炭素数 2〜18 のものが合成されてい る。著者らす化学構造と抗酸化性の関係を知るために炭素数, 2 , 6，8 のアルキル基を有する 4-アルキルピロカテコール拈よび, その外三，三のピロカテコール誘導体を合成した。

2) Morris, Riemenschneider, J. Am. Oil Chemists' Soc. 26, 638 (1949).

3) Bickoff, ibid. 28, 65 (1951).

4) Miller, Hartung, Rock, Crossley, J. Am. Chem. Soc. 60, 7 (1938).

5) Haworth, Woodcock, J.Chem. Soc. 1946, 999.

6) 田村，大久保，金田，燶化 28，4 (1954)。
合成はベラトロールと酸塩化物を無水塩化アルミニウムの存在 下で縮合させて 4-アシルベラトロールをつくり，クレメンゼン および, ウォルフ・キッスナー法により還元して4ーアルキルヘ ラトロールとしたのち，48\% 臭化水素酸と酢酸で脱メチルをす る従来と同様な方法によって目的物をえた。

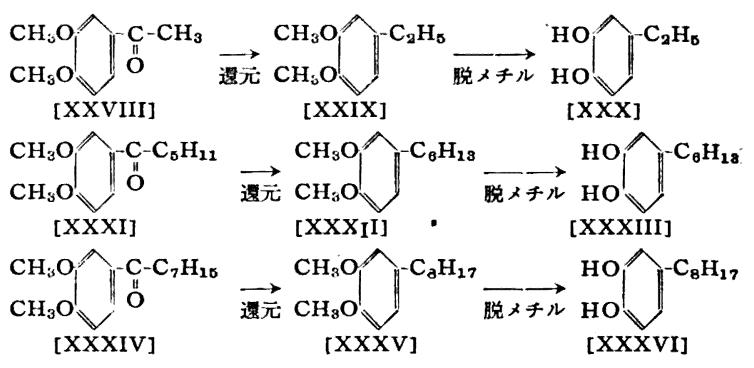

安息香酸および, $p$-位置に $\mathrm{NO}_{2}, \mathrm{CH}_{3} \mathrm{O}$, 等の置換基をるつ安 息香酸クロリドとベラトロールとの縮合も上述の方法と全く同様 に行い，それぞれの目的物をえた。

安息香酸クロリドの場合には，ベラトロイルベンゼン [XXX VII]， ベラトリルベンゼン [XXXVIII]，および (3,4-ジオキシ ベンジル)ーベンゼン $[X X X I X]$ をえた。

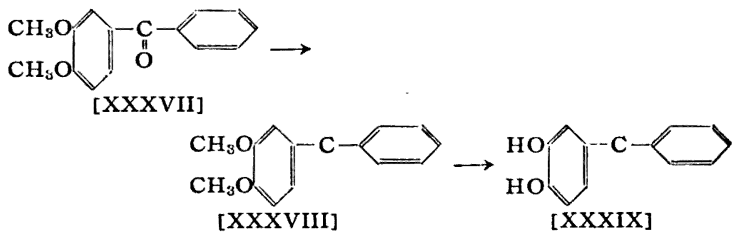

アニス酸クロリドの場合も同様にして，4-ベラトロイルアニソ ール $[\mathrm{XL}]$, ベラトリルアニソール $[\mathrm{XLI}], 4$ 4-(3,4-ジオキシ・・ ンジル)ーフェノール[XLII] をえた。

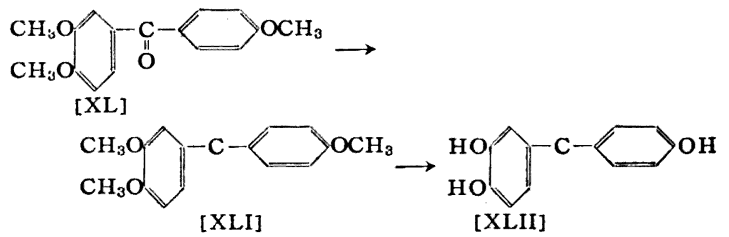

ヘキサデシル安息香酸クロリドの場合には, 1一へキサデシルー4ベラトロイルベンゼン [XLIII] をえたが，試料が少量のためそ の後の合成は行わなかった。

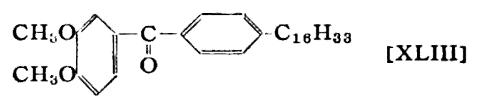

$p$-ニトロ安息香酸の場合は, ウォルフ・キッスナー法により, 4-ベラトロイルニトロベンゼン [XLIV] を睘元すると $\mathrm{NO}_{2}$ 基も 同時に還元されて，4-ベラトリルアニリン $[\mathrm{XLV}]$ がえられた。

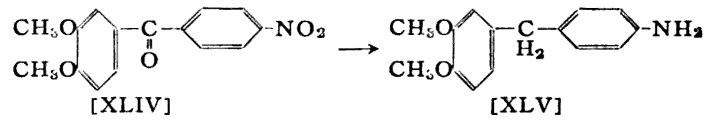

以上の合成によりえられたモノケトン $[\mathrm{XXXVII}],[\mathrm{XL}]$, [XLIII]，[XLIV] はそれぞれ 2,ージニトロフェニルヒドラゾン を生成する。

\section{抗酸化剂の合成}

本研究に使用した試料は市販品を精製またはとのまま用いた。 扣もなものの性状は次のと扣りである。

ベラトロール：ピロカテュール $\left(\mathrm{mp} 103 \sim 105^{\circ} \mathrm{C}\right)$ をジメチル 
硫酸とカセイソーダでメチル化して合成した。bp $203 \sim 206^{\circ} \mathrm{C}$, 収 禹 98\%である。

ヒドロキノンジメチルエーテル：市販 1 級品ヒドロキノンをジ

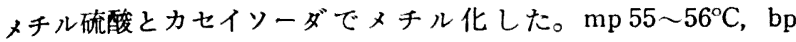
$208 \sim 210^{\circ} \mathrm{C}$ 。収率 $85 \%$ 。

レゾルシンジメチルエーテル：市肘 1 䄲レゾルシンを上氾と同 様にメチル化した。bp $215 \sim 217^{\circ} \mathrm{C}$ ，収率 $90 \%$ 。

テレフタル酸：テレフタル酸メチル $\left(\mathrm{mp} 140.5^{\circ} \mathrm{C}\right)$ をカセイカ リ水溶液でケン化してテレフタル酸をえた。昇華性。五塩化リン そ $140^{\circ} \mathrm{C}$ に 6 時間加熱してテレフタル酸ジクロリドをえた。 $\mathrm{mp}$ $77 \sim 80^{\circ} \mathrm{C}$ 。

イソフタル酸：bp 138.5 139. $0^{\circ} \mathrm{C}$ の m-キシレンを中性過 マ ンガン酸カリで酸化, 精製したるので, $\mathrm{mp} 346 \sim 348^{\circ} \mathrm{C}$ である。 酸化収率 $80 \%$ 。

無水フタル酸: $\mathrm{mp} 128 \sim 130^{\circ} \mathrm{C}$ 。

\section{(1) 1,4-ジヘララトロルベンゼン [I] の合成}

ベラトロール $150 \mathrm{~g}$ をテトラクロルエタン $200 \mathrm{cc}$ に溶解し, 水銀シールカキマゼ機, 還流冷却器を付した $1 l$ 三つロフラスコ に入れ氷冷しつつかきまぜる。これに粉末無水塩化アルミニウム $125 \mathrm{~g}$ を徐々に加える。後湯浴温度を $30^{\circ} \mathrm{C}$ に上昇してテレフタ ル酸ジクロリド $50 \mathrm{~g}$ を分液漏斗より約 1 時間にわたり滴下す る。滴下終了後，さらに温度を上昇して浴温 $50 \sim 60^{\circ} \mathrm{C}$ で 9 時間 かきませ， 1 昼夜放置後分解する。テトラクロルエタン層を水蒸 気蒸留に付し，残留物を熱ベンゼンに溶解して炭酸水素ナトリウ

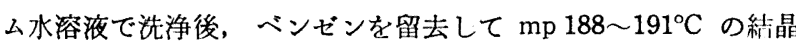
$80 \mathrm{~g}$ をえた。収率 79\%である。ベンゼン溶液で 2 回活性炭処 理を行い, mp 193. 5 194. $5^{\circ} \mathrm{C}$ の白色結晶をえた。

\begin{tabular}{|c|c|}
\hline 素分析 & \\
\hline $\mathrm{C}_{24} \mathrm{H}_{22} \mathrm{O}_{6}$ として計算値 & $\begin{array}{l}71.39 \% \\
70.93\end{array}$ \\
\hline 2,4-ジニトロフェニルヒドラジン & $\begin{array}{r}\mathrm{N} \% \\
\text { 計 算 值 } \\
\text { 分解温度 }\end{array}$ \\
\hline
\end{tabular}

したがって本結晶は，1４-ジペラトロイルベンゼンよりなるも のと思われる。

（2）4-ヘララトロイル安息酸［II] の合成

上述のフリーデル・クラフッ反応生成物中, 炭酸水素ナトリウ 么水溶液に可溶性の物質を希塩酸で酸性にして析出する固体をわ かち, アルコールより 2 回再結晶して $\operatorname{mp} 216.0 \sim 217.6^{\circ} \mathrm{C}$ の白 色針状結晶をえた。ベンゼンに難溶性である。

元素分析

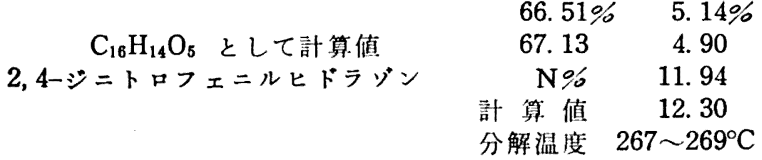

以上の性状よりして，4-ベラトロイル安息香酸よりなるものと 考えられる。

（3） 1,4-ジベラトリルベンゼン [III] の合成

ジケトン[I] $20 \mathrm{~g}$ に $80 \%$ ヒドラジンヒドラート $30 \mathrm{cc,} \mathrm{ジ}$ エチレングリコール $100 \mathrm{cc}$ を加え, 丸底フラスコに入れ凝縮器

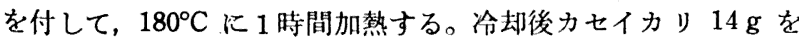
加之 $200^{\circ} \mathrm{C}$ に 2 時間加熱する。冷却後水中に投じ, 希塩酸で酸性 にしたのち析出する結晶を口過する。17.5 g の淡紅色の結晶を えた。 mp 95〜 $112^{\circ} \mathrm{C}$ を示し，一部分希アルカリリ夜に溶解すること
より，還元反応中に一部脱メチルされたものと思われる。ジメチ ル硫酸とカセイソーダでメチル化を行い，アルコールで 2 回再結

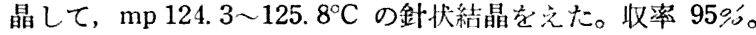
元素分折

（4） 1,4-ビス-(3,4-ジオキシベンジル)-ベンゼン [IV] の合 成

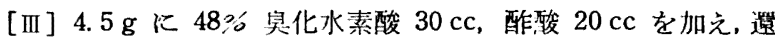
流冷却器を付して 5 時間煮沸する。减圧蒸留によって酢酸をのぞ き水中に投じて析出する結晶を口過する。アルコール溶液で活性 炭処理を行い，のちアルコールを留去し，少量の眽酸に溶解し水 を加えて結晶を析出させる。収率 $91 \%$ 。この精製法をくり返し て $\mathrm{mp} 212 \sim 214^{\circ} \mathrm{C}$ の針状結晶をえた。 元素分析

$\begin{array}{lll}\mathrm{C}_{20} \mathrm{H}_{18} \mathrm{O}_{4} & 74.92 \% & 5.89 \% \\ \text { として計算值 } & 74.53 & 5.59\end{array}$

（5）4-ヘララトリル安息香酸 [V] の合成

[II] のケト酸 $3.2 \mathrm{~g}$, ヒドラジンヒドラート $4.5 \mathrm{cc}$, ジェチ レングリコール $10 \mathrm{cc}$ カセイカリ $1.8 \mathrm{~g}$ を用い, ウォルフ・キッ スナー法により合成（3）の場合に準じて還元を行った。還元物 として $2.9 \mathrm{~g}$ をえた。収率 $95 \%$ 。メチル化してアルコールと水

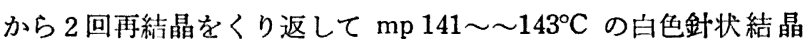
をえた。

元素分析

$\mathrm{C}_{16} \mathrm{H}_{16} \mathrm{O}_{4}$ として計算值

$\mathrm{C} \quad \mathrm{H}$

$70.32 \% \quad 5.67 \%$

$70.58 \quad 5.88$

（6） 4-(3,4-ジオキシベンジル)-安息香酸 [VI] の合成

[V] を $48 \%$ 舁化水素酸，溶媒として眽酸を用いて常法にし たがって脱メチルを行った。収率 $98 \%$ 。 $\mathrm{mp} 201 \sim 203^{\circ} \mathrm{C}$ の白色 針状結晶である。

元素分析

\section{$\mathrm{C}_{14} \mathrm{H}_{12} \mathrm{O}_{4}$ として計算值}

C

$69.00 \%$

$\mathrm{H}$

68.85

$4.85 \%$

4. 91

(7) 1,4-ビス-(3,4-ジオキシヘンソイル)-ベンゼン [VII] の合成

ジケトン [ I ] $10 \mathrm{~g}$ を $48 \%$ 臭化水素酸 $80 \mathrm{cc}$, 酷酸 $80 \mathrm{cc}$, 無 水酢酸 $20 \mathrm{cc}$ とともに煮沸して脱メチルを行った。反応終了後水 中に投じてえた脱メチル化物はメタノールに溶解して活性炭処理 を行いメタノールを1部留去して水を加えて結晶を析出させた。 収量 $8 \mathrm{~g}$ で収率は 93\%である。 $\mathrm{mp} 262^{\circ} \mathrm{C}$ 。微淡黄緑出である。

\begin{tabular}{|c|c|c|}
\hline 元素分析 & C & $\mathrm{H}$ \\
\hline $\mathrm{C}_{20} \mathrm{H}_{14} \mathrm{O}_{6}$ として計算值 & $\begin{array}{l}\text { 68. } 13 \% \\
68.57\end{array}$ & $\begin{array}{l}3.90 \% \\
4.00\end{array}$ \\
\hline ージニトロフェニルヒドラジン & $\mathrm{N} \%$ & 14. 91 \\
\hline & 算 值 & $\begin{array}{l}15.69 \\
310^{\circ} \mathrm{C} \text { 以上 }\end{array}$ \\
\hline
\end{tabular}

したがって本結晶は，1,4-ビスー(3,4-ジオキシペンソ゚イル)ーベ ンゼンであると推定される。

(8) 1,4-ビス-(2,5-ジメトキシベンゾイル)-ベンゼン[VIII] の合成

ヒドロキノンジメチルエーテルとテレフタル酸ジクロリドを無 水塩化アルミニウムを触媒として合成（1）に準じて樎合させ た。フリーデル・クラフッ反応の際の反応混合物は, 赫色を呈 し $50^{\circ} \mathrm{C}$ でかきぜをつゔけると䄪 1 時間で粘椆となり,ついには 固化する。濃塭酸と砕氷で分解して常法により後処理を行った。ジ 
ケトンは mp 148〜 $150^{\circ} \mathrm{C}$ を示し, 収率 $80 \%$ であった。ベンゼ ンより再結晶して mp 149.0 150. $0^{\circ} \mathrm{C}$ の微淡緑色の針状結晶を えた。

元素分析

$\mathrm{C}_{24} \mathrm{H}_{22} \mathrm{O}_{6}$ として計算值

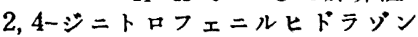

$\begin{array}{cc}\mathrm{C} & \mathrm{H} \\ 71.25 \% & 5.80 \% \\ 70.93 & 5.41 \\ \mathrm{~N} \% & 13.98 \\ \text { 計 算值 } & 14.50 \\ \text { 分解温度 } & 294^{\circ} \mathrm{C}\end{array}$

以上の性状よりして 1,4-ビスー (2,5-ジメトキシベンゾイル)ベンゼンと推定される。

（9）4-(2,5-ジメトキシベンゾイル)-安㫣香酸 [IX] の合成 上述のフリーデル・クラフッ反応に拉いて, 炭酸水素ナトリウム 水溶液に可溶性物質をアルコールより数回再結晶して $\mathrm{mp} 170.0$ 〜 $171.5^{\circ} \mathrm{C}$ の針状結晶をえた。

元素分析

$\begin{array}{ccc}\mathrm{C}_{16} \mathrm{H}_{14} \mathrm{O}_{5} \text { として計算值 } & 66.95 \% & \mathrm{C} \\ & 67.13 & 4.98 \% \\ & \mathrm{~N} \% & 11.64 \\ & \text { 計 算 值 } & 12.30 \\ & \text { 分解温度 } & 150 \sim 152^{\circ} \mathrm{C}\end{array}$

(10） 1,4-ビス-(2,5-ジメトキシベンジル)-ベンゼン [X] の 合成

（3）に準じてウォルフ・キッスナー法により還元を行った。還 元反応終了後水中に投じて析出する結晶を集め, アルコールで再 結晶を行うと $\mathrm{mp} 105 \sim 108^{\circ} \mathrm{C}$ の結晶を弓る。収率 $89 \%$ 。アルコ ールより再結晶をくり返して mp 107.5 108. $8^{\circ} \mathrm{C}$ の白色針状結 晶をえた。

\begin{tabular}{llll} 
元素分析 & \multicolumn{1}{c}{ C } & \multicolumn{1}{c}{$\mathrm{H}$} \\
$\mathrm{C}_{24} \mathrm{H}_{26} \mathrm{O}_{4}$ & として計算值 & $76.27 \%$ & $7.21 \%$ \\
& 76.19 & 6.87
\end{tabular}

(11） 4-(2,5-ジメトキシベンジル)-安息香酸 [XI] の合成

ウォルフ・キッスナー法により，（5）に準じて [IX] のケト

酸 $6 \mathrm{~g}$ を還元した。収量 $5 \mathrm{~g}$, 収率 $95 \%$ 。 $\mathrm{mp} \mathrm{164.8 \sim 166.} 0^{\circ} \mathrm{C}$ 。 元亲分析

(12) 1,4

[X] $10 \mathrm{~g}$ を用い,（4）に準じて脱メチルを行った。この際の 煮沸時間は 15 時間で生成物の収量 $7.2 \mathrm{~g}$, 収率 $85 \%$ 。 $\mathrm{mp} 202$ 〜2(3C の白色針状結晶であった。

\section{元素分析}

$\mathrm{C}_{20} \mathrm{H}_{18} \mathrm{O}_{4}$ として計算値

(13） 1-(ヘラトロイル)-4-(2, 5-ジメトキシヘンンジル)-ベンゼ ン [XIII] の合成

[XI] $8.5 \mathrm{~g}$ をクロロホルムに溶解し五塩化リン $10 \mathrm{~g}$ を加え て, 湯浴上で 30 分間加温する。クロロホルムおよびオキシ塩化 リンを減圧で留去すると酸クロリドがえられる。

ベラトロール $16 \mathrm{~g}$, 上記の酸クロリド $9 \mathrm{~g}$ および塩化アルミ ニウム $8 \mathrm{~g}$ を用いてフリーデル・クラフッ反応を行った。ベラト ロール，酸クロリド, テトラクロルェタンの混合物を $0^{\circ} \mathrm{C}$ 以下に 冷却して粉末無水塩化アルミニウムを徐々に加える。䄪 2 時間水 浴でかきまぜてのち，室温で 24 時間，ときどきかきまぜて放篗 した。常法により後処理を行い, 水蒸気蒸留を行ったのちに残留 する固塊をベンゼンに溶解して活性炭処理後ベンゼンを留去し，
メタノールを加えてしばらく放置すると結晶が析出する。収量は $12 \mathrm{~g}$ で収率 99\% である。メタノールより再結晶して mp 101.5 〜 $102.5^{\circ} \mathrm{C}$ の白色針状結晶をえた。

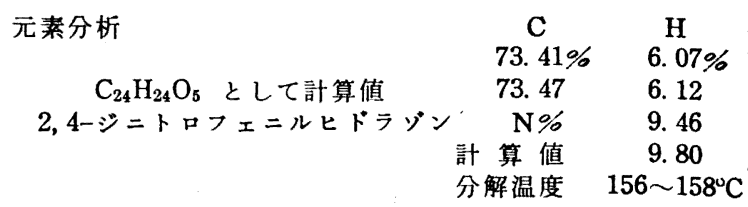

以上の結果からみて本結晶は 1-(ベラトロイル)-4-(2, 5-ジメ トキシベンジル)ーベンゼンであることが推定されだ。

(14） 1-(ヘラトリル)-4-(2,5-ジメトキシヘンジル)-ベンゼン [XIV] の合成

[XIII] $11.0 \mathrm{~g}$ を合成（3）に準じてウォルフ・キッスナー法 により還元を行った。収量 $7.2 \mathrm{~g}$, 収率 $68 \%$ 。メタノールを溶 媒として活性岑処理, 再結晶を行って $\mathrm{mp} 63.1 \sim 64.6^{\circ} \mathrm{C}$ の白色 針状結晶をえた。

元素分析

$\mathrm{C}_{24} \mathrm{H}_{26} \mathrm{O}_{4}$ として計算值

$\begin{array}{ll}\text { C } & \text { H } \\ 75.98 \% & 6.94 \% \\ 76.19 & 6.87\end{array}$

(15） 1-(3, 4-ジオキシヘンジル)-4-(2, 5-ジオキシベンジル)ベンゼン $[\mathrm{XV}]$ の合成

[XIV] を $48 \%$ 臭化水素酸で合成 (4) に準じて脱メチルを行 った。収率 $54 \%$ 。 $\mathrm{mp} 189 \sim 191^{\circ} \mathrm{C}$ 。

元素分析

$\mathrm{C}_{20} \mathrm{H}_{18} \mathrm{O}_{4}$ として計算值

\begin{tabular}{ll}
$\mathrm{C}$ & \multicolumn{1}{c}{$\mathrm{H}$} \\
$74.48 \%$ & $5.68 \%$ \\
74.53 & 5.59
\end{tabular}

（16）レゾルシンジメチルエーテルとテレフタル酸ジクロリド のフリーデル・クラフッ反応について

(a) レゾルシンジメチルエーテル $75 \mathrm{~g}$ ，テレフタル酸ジク ロリド $25 \mathrm{~g}$, 無水塩化アルミニウム $65 \mathrm{~g}$ を用い, 合成 (1)に 準じてフリーデル・クラフッ反応を行った。反応温度を $45^{\circ} \mathrm{C} に$ 保ってかきまぜると 4 時間後にはかきまぜることが困難になる。 常法にしたがって後処理を行い, ジケトン部分として淡緑色結晶

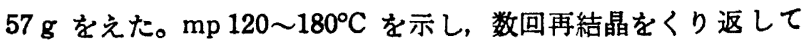
す精製は不可能であった。この結晶は 2,4ージニトロフェニルヒ ドラゾンを生成し分解温度 $280^{\circ} \mathrm{C}$ 以上を示した。

（b）つぎにレゾルシンジメチルェーテルとテレフタル酸ジク ロリドをモル比 $(1.2: 1)$ にとり, 反応温度を $30^{\circ} \mathrm{C}$ に保って 24 時間反応させた。ジケトンをベンゼンで数回再結晶して少量の純

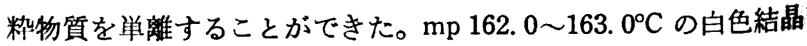
である。

元素分析

$$
\begin{aligned}
& \mathrm{C}_{24} \mathrm{H}_{22} \mathrm{O}_{6} \text { として計算値 } \\
& \text { 2,4-ジニトロフェニルヒドラゾン } \\
& \begin{array}{ll}
70.93 & 5.41
\end{array} \\
& \mathrm{~N} \% \quad 13.93 \\
& \text { 計算值 } 14.50 \\
& \text { 分解温度 } 280^{\circ} \mathrm{C}
\end{aligned}
$$$$
\text { H }
$$$$
71.02 \% \quad 5.33 \%
$$

本結晶は 1,4-ビスー(ジメトキシベンゾイル)ーベンゼン [XVI] であると推定される。

また後処理において炭酸水素ナトリウム水溶液に可溶の酸性物 質としてヶト酸がえられた。 $\mathrm{mp} 171 \sim 175^{\circ} \mathrm{C}$ 。アルコールより再 絬晶して mp 176.0〜178. $0^{\circ} \mathrm{C}$ の白色針状結晶をえた。ベンゼン に難溶である。

元素分析

$\mathrm{C}_{16} \mathrm{H}_{14} \mathrm{O}_{5}$ として計算值

C

$66.62 \%$ $\mathrm{H}$

$14 \%$

90 


$$
\begin{aligned}
& \text { 2,4-ジニトロフェニルヒドラジン } \mathrm{N} \% \quad 11.83 \\
& \text { 計 算 值 } 12.30 \\
& \text { 分解温度 } 164 \sim 166^{\circ} \mathrm{C}
\end{aligned}
$$

以上の結果から本結晶は 4-(ジメトキシベンゾイル)一安息香酸 と推定される。

\section{（17） 1，3-ジベラトロイルベンゼン [XVIII] の合成}

イソフタル酸ジクロリドとベラトロールを反応条件を合成 (1) に準じて無水塩化アルミニウムを触媒として縮合させた。ジケト ンは mp 192.5 193. $5^{\circ} \mathrm{C}$ の白色結晶である。融点は [ I ] に接

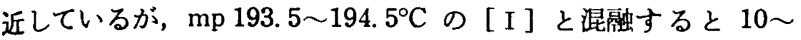

\begin{tabular}{|c|c|c|}
\hline 元萦分析 & $\mathrm{C}$ & $\begin{array}{l}\mathrm{H} \\
5.69 \%\end{array}$ \\
\hline $\mathrm{C}_{24} \mathrm{H}_{22} \mathrm{O}_{6}$ として計算值 & $\begin{array}{l}70.54 \% \\
70.93\end{array}$ & $\begin{array}{l}5.69 \% \\
5.41\end{array}$ \\
\hline 2,4 -ジニトロフェニルヒドラジン & $\mathrm{N} \%$ & 14.34 \\
\hline & $\begin{array}{l}\text { 算 值 } \\
\text { 解温度 }\end{array}$ & $\begin{array}{c}14.50 \\
256 \sim 259^{\circ} \mathrm{C}\end{array}$ \\
\hline
\end{tabular}
$15^{\circ} \mathrm{C}$ の融点降下がみとめられ，［Ｉ］と同一物質でないことを確 認した。ジケトンの収率は $57 \%$ である。

\section{（18）3-ベラトロイル安息番酸 $[X I X]$ の合成}

上記フリーデル・クラフッ反応生成物を炭酸水素ナトリウム水 溶夜で抽出してヶト酸を単離し, 合成 (2) の場合と同様にして

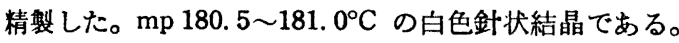

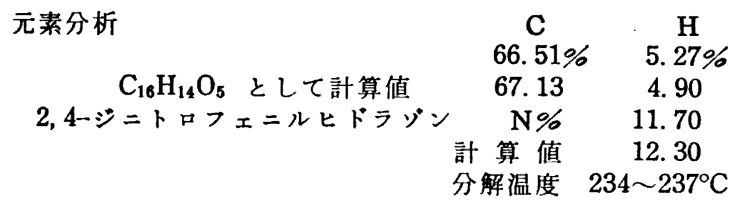

（19）１，3-ジベラトリルベンゼン［XX] の合成

ジケトン [XVIII] をウォルフ・キッスナー法により [I] の還 元と同様に行った。収率 $63 \%$ mp $67.8 \sim 68.6^{\circ} \mathrm{C}$ の针次站晶を えた。

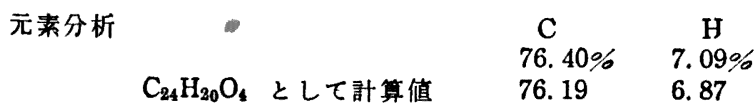

(20）3ーヘラトリル安虫䣹 [XXI] の合成

ケト酸 $[\mathrm{XIX}]$ を常法にしたがってウォルフ・キッスナー法に より還元して 3ーベラトリル安息香酸をえた。収率 $60 \%$ 。 $\mathrm{mp}$ 111.3〜 $112.5^{\circ} \mathrm{C}$ の白色針状結晶である。

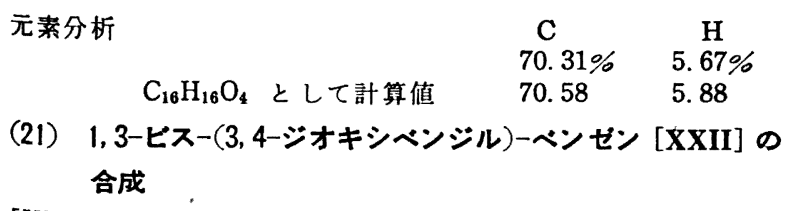

$[X X]$ を臭化水素酸と酶酸妾用いる常法にしたがって脱メチル を行い, 1,3-ビスー(3,4-ジオキシベンジル)ーベンゼンをえた。収

\begin{tabular}{|c|c|}
\hline & $\underset{74.86 \%}{C}$ \\
\hline $\mathrm{C}_{20} \mathrm{H}_{18} \mathrm{O}_{4}$ として計算值 & 74.53 \\
\hline
\end{tabular}

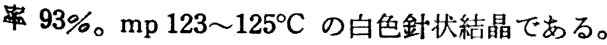

元素分析

\section{（22）3-(3,4-ジオキシヘンンジル)-安息香酸 [XXIII] の合成}

[XXI] を $48 \%$ 臭化水素酸と酢酸を用いて常法にしたがって 脱メチルした。収率 $63 \%$ 。 mp 174〜176 ${ }^{\circ} \mathrm{C}$ の白色針状結晶をえ た。

\begin{tabular}{lllll} 
元素分析 & & & \multicolumn{1}{c}{$\mathrm{C}$} & \multicolumn{1}{c}{$\mathrm{H}$} \\
& & $68.87 \%$ & $5.01 \%$ \\
& $\mathrm{C}_{14} \mathrm{H}_{12} \mathrm{O}_{4}$ & として計算值 & 68.85 & 4.91
\end{tabular}

(23) 1,3-ビスー(3,4-ジオキシヘンンソイル)-ヘンンゼン [XXIV]
の合成

合成 (7) に準じてジヶトン [XVIII] $2.5 \mathrm{~g}$ を $48 \%$ 具化水 素酸 $5 \mathrm{cc}$, 酢酸 $10 \mathrm{cc}$, 無水眽酸 $5 \mathrm{cc}$ ととるに 5 時間煮沸して 脱メチルを行った。脱メチル化物の収量は $1.9 \mathrm{~g}$ で収率は $88 \%$ である。 $\mathrm{mp} 252.5^{\circ} \mathrm{C}$ ( $158^{\circ} \mathrm{C}$ で収縮) の白色針状結晶をえた。 元素分析

\begin{tabular}{ll}
$\mathrm{C}$ & \multicolumn{1}{c}{$\mathrm{H}$} \\
$67.97 \%$ & $3.85 \%$ \\
68.57 & 4.00
\end{tabular}

（24）ヒドロキノンジメチルェーテルとインフタル酸ジクロリ ドのフリーデル・クラフッ反応について

前述の合成（1）と同じ反応条件でヒドロキノンジメチルエー テルとイソフタル酸ジクロリドを縮合させた。反応生成物は樹脂 状粘着物質を多量に含み, ベンゼンに対する溶解性は大で結晶し がたい性質のものである。しかし酢酸とメタノールを用いて再結 晶を数回くり返して少量のジケトンとケト酸を単離することがで きた。ジケトンは mp 79.5 81. $5^{\circ} \mathrm{C}$ の白色針状結晶である。

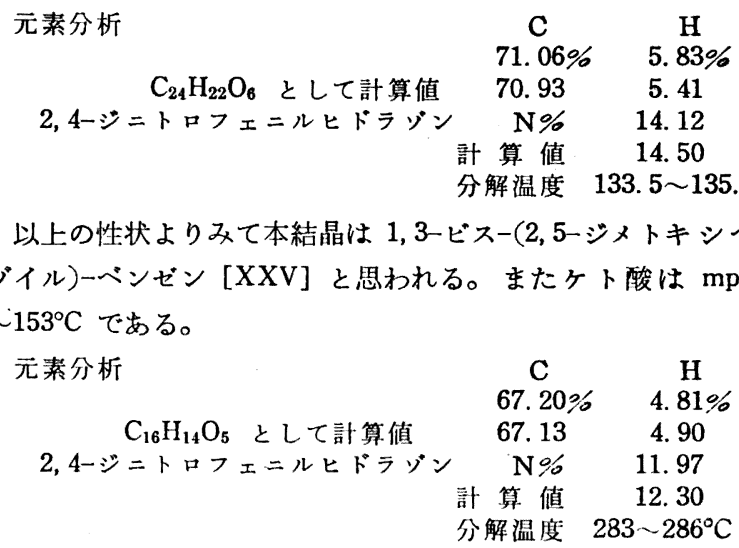

元素分析絬果は 3-(2,5-ジメトキシベンゾイル)-安息香酸 [XXVI] とょく一致している。

（25）１，2-ジベラトロイルベンゼン［XXVII] の合成

合成（1）に準じてフタル酸ジクロリドとベラトロールを無水 塩化アルミニウムの存在下で縮合させた。合成（1）の場合とこ となる点は, 低温度に批いてす盛に塩酸ガスを発生して反応が進 行するので, $-10^{\circ} \mathrm{C}$ 以下でべラトロールとフタル酸ジクロリド, テトラクロルエタンの混合物をかきまぜつつ粉末無水塩化アルミ ニウムを徐々に加え，後室温 $\left(20^{\circ} \mathrm{C}\right)$ で約 3 時間かきまぜて反応 を終了した。常法にしたがって後処理を行い, えた絬晶をメタノ ールで 1 回洗浄すれば mp 149.9〜151. 5C を示した。少量のべ ンゼンに溶解し，メタノールを加えて再結晶すれば $\mathrm{mp} 152.0$ 〜 $152.5^{\circ} \mathrm{C}$ となる。2,4-ジニトロフェニルヒドラジン，七ミカルパ ゾンを生成しない。

元䊝分析

\begin{tabular}{lll}
$\mathrm{C}_{24} \mathrm{H}_{22} \mathrm{O}_{6}$ として計算值 & $71.18 \%$ & $5.92 \%$ \\
\hline
\end{tabular}

(26）p-tert-ブチルベラトロールとテレフタル酸ジクロリドの フリーデル・クラフッ反応について

-tert-ブチルベラトロール $0.4 \mathrm{~mol}$, テレフタル酸ジクロリド $0.1 \mathrm{~mol}$, および無水塩化アルミニウムの当量を用い, 合成 $(1)$ の場合と同様にしてフリーデル・クラフッ反応を行った。ジケト ンは mp 193.5 194. $0^{\circ} \mathrm{C}$ を示し，メトキシ基 $31.70 \%$ (1,4-ジ ベラトロイルベンゼンとしての計算值は 30.54\%) であり， [I] と混骶して融点の低下を示さず，したがって［I］と同一物質で 
あり tert-ブチル基は脱アルキルされたことをみとめた。

\section{（27）4-アルキルピロカテコールの合成}

(a) 4-エチルピロカテュール [XXX] の合成: 一一

i）4-アセチルベラトロール [XXVIII] : ベラトロール $40 \mathrm{~g}$, 無水酢酸 $26 \mathrm{~g}$ をテトラクロルエタン $200 \mathrm{cc}$ にとかし， $-10^{\circ} \mathrm{C}$ に冷却かきまぜつつ粉末無水塩化アルミニウム $52 \mathrm{~g}$ を徐々に加 える。後浴の温度を上惖して $10 \sim 15^{\circ} \mathrm{C}$ に 3 時間かきまぜて反応 を䅂了して塩酸と砕水で分解寸る。テトラクロルエタン層を水蒸 気蒸留に付し, 残留物をエーテルで抽出し, 脱水乾燥後エーテル を留去し, 減圧蒸留を行い bp $132 \sim 134^{\circ} \mathrm{C} / 3 \mathrm{mmHg}$ で留出する 液体をあつめた(文献值 $170 \sim 175^{\circ} \mathrm{C} / 15 \mathrm{mmHg}^{6}$ ))。 $\mathrm{mp} 45 \sim 48^{\circ} \mathrm{C}_{\text {。 }}$ 収量 $15 \mathrm{~g}$, 収率 $30 \%$ (ニトロベンゼンを溶媒とした場合の文 献家)収率 60\%分。

ii）4-エチルベラトロール [XXIX]: [XXVIII] $9.0 \mathrm{~g}$, 垔鉛 アマルガム $25 \mathrm{~g} ， 20 \%$ 塩酸 $40 \mathrm{cc}$ を用いてクレメンゼン法によ り還元を行った。煮沸時間 21 時間。反応終了後エーテル抽出を 行い, エーテル層を水洗脱水乾燥して减圧蒸留を行い, bp 99 $100^{\circ} \mathrm{C} / 5 \mathrm{mmHg}$ の留分 $5.0 \mathrm{~g}$ をえた。収率 $60.2 \%$ (文献倠 150 ${ }^{\circ} \mathrm{C} / 55 \mathrm{mmHg}$, 収率 $\left.50 \%{ }^{6)}\right)$ 。

iii） 4-エチルピロカテュール [XXX]: [XXIX] $4 \mathrm{~g}$ を 48\% 臭化水素酸と酢酸を用いて脱メチルした。生成物は bp 119 120 ${ }^{\circ} \mathrm{C} / 4 \mathrm{mmHg}$ である。収量 $3 \mathrm{~g}$, 収率 $90 \%$ (文献值 $130 \sim 132^{\circ} \mathrm{C} /$

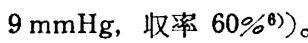

(b) 4-ヘキシルピロカテュール [XXXIII] の合成：-

i）4-カプロイルベラトロール [XXXI]：[XXVIII] の場合に 準じカプロン酸クロリドそべラトロールを無水塩化アルミニウム の存在下に縮合させた。生成物は bp $164 \sim 166^{\circ} \mathrm{C} / 5 \mathrm{mmHg}$ であ る。収率 $51 \%$ (文献值 $178^{\circ} \mathrm{C} / 17 \mathrm{mmHg}$, 収率 $53 \% \%^{6)}$ )。

ii）4一ヘキシルベラトロール [XXXII]: [XXXI]を常法にし たがってクレメンゼン法により還元した。生成物は bp 136〜138 ${ }^{\circ} \mathrm{C} / 4 \mathrm{mmHg}$ である。収率 $61 \%$ (文献值 $155 \sim 160^{\circ} \mathrm{C} / 11 \mathrm{mmHg}$, 収率 76\% ${ }^{\text {)) }}$ 。

iii） 4ーヘキシルピロカテコール [XXXIII]：[XXXII] を臭化 水素酸と酢酸を用いて脱メチルした。生成物は bp $169 \sim 172^{\circ} \mathrm{C} / 5$ $\mathrm{mmHg}$ である。収率 $57 \%$ (文献值 $164 \sim 170^{\circ} \mathrm{C} / 5 \mathrm{mmHg}$, 収率 $\left.51 \%{ }^{6)}\right)$ 。(164 $\left.169^{\circ} \mathrm{C} / 5 \mathrm{mmHg}^{4}\right)$ )。

(c) 4-オクチルピロカテコール [XXXVI]：

i）4ーカプロイルペラトロール (XXXIV]: [XXXI] の場合に 準じ，カプリル酸クロリドとべラトロールを無水塩化アルミニウ ムを触媒として縮合させた。収率 $45 \%$ 。メタノールより 2 回再 結晶をくり返して mp 49.0 50. $0^{\circ} \mathrm{C}$ の白色針状結晶をえた。

2,4-ジニトロフェニルヒドラジン $\mathrm{N} \% \quad 12.53$ 計算值 12.64 分解温度 $130 \sim 131^{\circ} \mathrm{C}$

ii）4-オクチルベラトロール [XXXV]: [XXXIV] を常法に したがってクレメンゼン法により還元した。生成物は bp 169 $170^{\circ} \mathrm{C} / 5 \mathrm{mmHg}$ である。収率 $49 \%$ 。またジェチレングリコール と少量の石炭酸を溶媒としてウォルフ・キッスナー法により還元 すれば収率 $84.4 \%$ で生成物をえた。

iii）4ーオクチルピロカテコール [XXXVI]：[XXXV]を曼化 水素酸により常法に従って脱メチルした。生成物は bp 189 192 ${ }^{\circ} \mathrm{C} / 7 \mathrm{mmHg}$ である。収率 $68 \%$ (文献值 bp $175 \sim 180^{\circ} \mathrm{C} / 5 \mathrm{mmHg}^{6}$ )

（28）（3,4-ジオキシベンジル)-ベンゼン［XXXIX] の合成 (a) ベラトロイルベンゼン [XXXVII] の合成:- -

合成 (27) のフリーデル・クラフッ反応に準じて安息香酸ク口 リドとベラトロールを, 無水塩化アルミニウムを触媒として縮合 させた。モノケトン収率 $55 \%$ 。タノールで 2 回再結晶して mp 99. 5〜 100. $0^{\circ} \mathrm{C}$ の白色針状結晶をえた。

\begin{tabular}{|c|c|c|}
\hline 素分析 & C & $\mathrm{H}$ \\
\hline & $74.47 \%$ & $6.14 \%$ \\
\hline 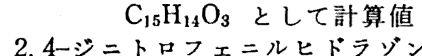 & $\begin{array}{r}74.38 \\
\mathrm{~N} \%\end{array}$ & $\begin{array}{r}5.78 \\
12.75\end{array}$ \\
\hline シニトロフェニルヒドラジン & $\begin{array}{l}\mathrm{N} \% \\
\text { 算 值 } \\
\text { 解温度 }\end{array}$ & $\begin{array}{c}12.75 \\
13.27 \\
211 \sim 212^{\circ} \mathrm{C}\end{array}$ \\
\hline
\end{tabular}

（b） ベラトリルベンゼン [XXXVIII] の合成：-

[XXXVII] を常法にしたがってウォルフ・キッスナー法によ り還元した。溶媒としてジェチレングリコールと少量の石炭酸 用いた。生成物の沸点は $177 \sim 179^{\circ} \mathrm{C} / 5 \mathrm{mmHg}$ である。収率 64 $\%$ 。

元素分析

$\mathrm{C}_{15} \mathrm{H}_{16} \mathrm{O}_{2}$ として部算值 $\quad 78.94 \quad 7.02$

(c) (3,4-ジオキシペンジル)ーベンゼン[XXXIX]の合成：-

[XXXVIII] を 48\% 臭化水素酸を用いて常法にしたがって脱 メチルした。收率 $86 \%$ 。 bp $207 \sim 209^{\circ} \mathrm{C} / 7 \mathrm{mmHg}, \mathrm{mp} 89.0$ $91.0^{\circ} \mathrm{C}$ の白色針状結晶である。

元素分析

\begin{tabular}{|c|c|c|}
\hline & $\begin{array}{c}\mathrm{C} \\
78.34 \%\end{array}$ & $\begin{array}{c}\mathrm{H} \\
5.87 \%\end{array}$ \\
\hline $\mathrm{C}_{13} \mathrm{H}_{12} \mathrm{O}_{2}$ として部算值 & 78.00 & 600 \\
\hline
\end{tabular}

(29） 4-(3,4-ジオキシベンジル)ーフェノール [XLII] の合成

(a) 4-ベラトロイルアニソール $[\mathrm{XL}]$ :

アニス酸クロリド $15 \mathrm{~g}$ とベラトロール $12 \mathrm{~g}$ を無水塩化アル ミニウムを触媒として縮合させた。モノケトン収量 $15 \mathrm{~g}$ 。収率 $65 \%$ 。メノールより 2 回再結晶すれば $\mathrm{mp} \mathrm{100} \mathrm{101.} 5^{\circ} \mathrm{C}$ の白 色針状結晶をえた。

元素分析

$\mathrm{C}_{16} \mathrm{H}_{16} \mathrm{O}_{4}$ として計算值

\section{C} $70.95 \%$

$\mathrm{H}$

70.58

$6.09 \%$

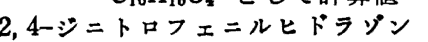

$\mathrm{N} \%$

5.88

計算值

12. 75

分解温度 $181.5 \sim 182.5^{\circ} \mathrm{C}$

(b) 4-ベラトリルアニソール [XLI] の合成: 一

[XL] をウォルフ・キッスナー法によって還元した。生成物は bp $210 \sim 212^{\circ} \mathrm{C} / 9 \mathrm{mmHg}$ である。収率 $74 \%$ 。

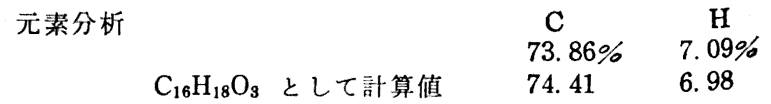

(c) 4-(3,4-ジオキシベンジル)ーフェノール[XLII]の合成:[XLI] を臭化水素酸により常法にしたがって脱メチルした。 bp $213 \sim 215^{\circ} \mathrm{C} / 4 \mathrm{mmHg}$ 。収率 $72 \%$ 。

元素分析

$\begin{array}{lll}\mathrm{C}_{13} \mathrm{H}_{12} \mathrm{O}_{3} \text { として計算值 } & 72.32 \% & 5.21 \% \\ & 72.22 & 5.56\end{array}$

（30）1-ヘキサデシル-4-ヘララトロイルベンゼン［XLIII］の 合成

ヘキサデシル安息香酸 $\left(\mathrm{mp} 99 \sim 100^{\circ} \mathrm{C}\right) 6 \mathrm{~g}$ に塩化チオニル $10 \mathrm{~g}$ を加え, 湯浴上で 1 時間 $70^{\circ} \mathrm{C}$ に加温する。このようにして えた酸クロリド $6.5 \mathrm{~g}$ とベラトロール $2.4 \mathrm{~g}$ をテトラクロルエ タン $100 \mathrm{cc}$ に溶解し, $-10^{\circ} \mathrm{C}$ に冷却して粉末無水塩化アルミ二 ウム $2 \mathrm{~g}$ を徐々に加える。のち温度を上昇して室温で 3 時間かき 
まぜて分解する。モノケトンは $\mathrm{mp} 84 \sim 86^{\circ} \mathrm{C}$ の白色結晶である。

$$
\begin{aligned}
& \text { 元素分析 } \\
& \mathrm{C}_{31} \mathrm{H}_{40} \text { として計算值 } \\
& \text { 80. } 09 \\
& \text { 79. } 83 \\
& \begin{array}{ll}
\mathrm{H} \\
09 \% & 10.45 \%
\end{array} \\
& \mathrm{~N} \%
\end{aligned}
$$

（31）4-ベラトロイルニトロベンゼン [XLIV] および，4-ヘ ラトリルアニリン $[\mathrm{XLV}]$ の合成

(a) 4-ベラトロイルニトロベンゼン [XLIV]

pーニトロ安息香酸クロリドとペラトロールを無水塩化アルミニ ウムを触媒として, 温度 $50^{\circ} \mathrm{C} て ゙$ 約 2 時間かきまぜて縮合させ た。粗モノケトン収量 $34 \mathrm{~g}$ 。収率 $74 \%$ 。ベンゼンより再結晶し て $\mathrm{mp} 171.2 \sim 172.5^{\circ} \mathrm{C}$ の黄色針状結晶をえた。

$$
\begin{aligned}
& \text { 元素分析 } \\
& \mathrm{C}_{15} \mathrm{H}_{13} \mathrm{O}_{5} \mathrm{~N} \text { として計算値 } \\
& 62.87 \% \\
& 62.72 \\
& \text { 2, 4-ジニトロフェニルヒドラジン N } \mathrm{N} \% \\
& \text { 計 算 值 } \\
& \text { 分解温度 }
\end{aligned}
$$

(b) 4-ベラトリルアニリン [XLV]:-

[XLIV] をウォルフ・キッスナー法によって 180〜200 C て 6 時間還元を行った。生成物をメタノールと水より再結晶して $\mathrm{mp}$ 103. 0〜 104. $5^{\circ} \mathrm{C}$ の針状結晶をえた。希塩酸溶液によく溶解する。

\begin{tabular}{llll} 
元素分析 & & \multicolumn{1}{c}{$\mathrm{C}$} & \multicolumn{1}{c}{$\mathrm{H}$} \\
& & $74.46 \%$ & $7.19 \%$ \\
& $\mathrm{C}_{15} \mathrm{H}_{17} \mathrm{O}_{2} \mathrm{~N}$ として計算值 & 74.07 & 6.99
\end{tabular}

\section{化学構造とパラフィンワックスに対する抗酸化性}

上述の合成によってえた化合物についてパラフィンワックスに 対する抗酸化性を測定し,化学構造と抗酸化性との関係を求めた。

酸化防止剤の抗酸化能は基油の種類如何によって大いに差異を 生じるものであるから，パラフィンワックスに対する抗酸化性の 優劣のみからその物質の抗酸化能を決定づけることは危険である が, 著者らは合成した物質の抗酸化能の大体の傾向を検する意味 で最も簡単な基油としてパラフィンワックスを選んだものであ

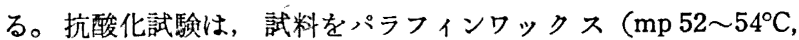
分子量：370）に0.01\% 添加して $160^{\circ} \mathrm{C}$ に打いて 1 時間 $2 l$ の 割合で空気を吹きこみ，過酸化物価 50 に達する時間を䇋導期間 とし，その時間でもって抗酸化性を比較した。测定方法等はすべ て前報7) と同様である。測定結果を第 1 表に示す。

以上の結果から化学構造とパラフインワックスに対する抗酸化 能との関係について若干の知見をうることができた。すなわち, 合成の最終目的物であるオキシ化合物は, いずれも優秀な抗酸化 能を示し，ことに [IV]，[XXII] は NDGA よりもはるかにす ぐれた抗酸化能をるつ。[XXXIII]，[XXXVI］のアルキルピロ カテコールもまたきわめて優秀な抗酸化能を示すが，眝藏中に漸 次着色する欠点がある。この点 [XXXIX] は変色せず優秀な抗 酸化能を有する。

ピロカテコール誘導体の抗酸化能は一般にヒドロキノン誘導体 よりも大きく，[XV] のように一方にピロカテコール核, 他方に ヒドロキノン核をるつ非対称の化学構造をるつるのは, 対称の構 造をもつ [IV] と [XII] との和の半分にほぼ等しい誘導期間を 示すことは，きわめて興味のあることと考える。

7) 山田, 寺町, 松田, 高分子化学 11, 521 (1954).

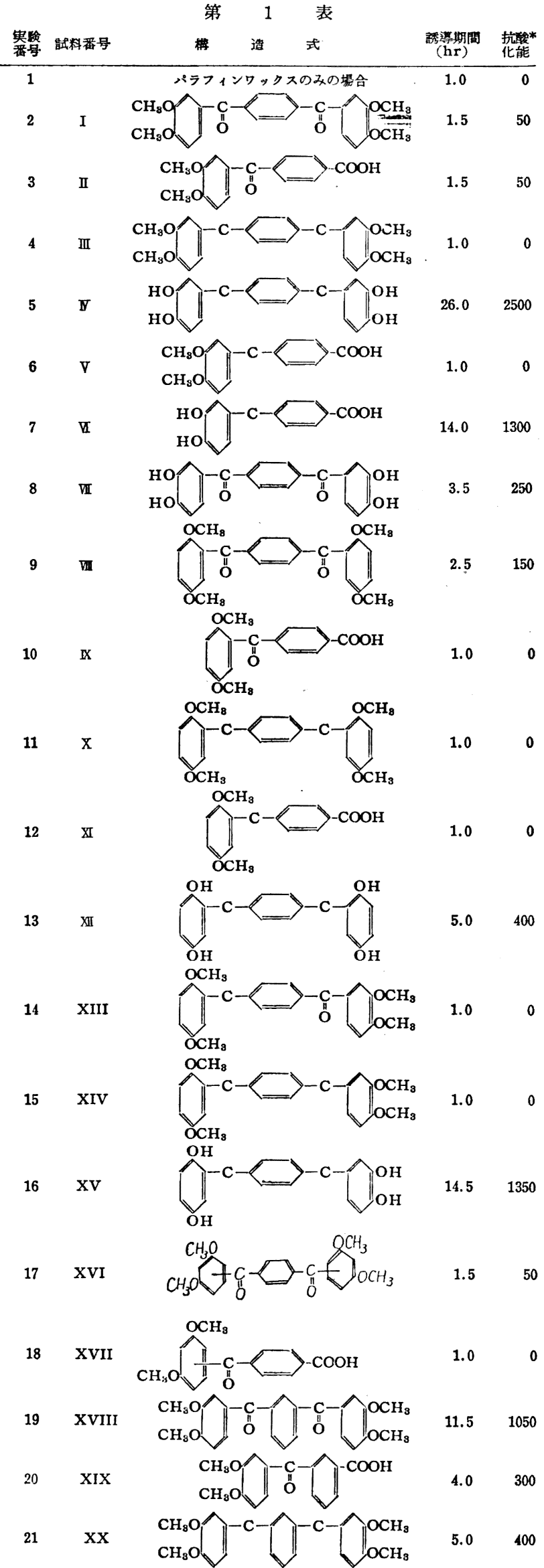




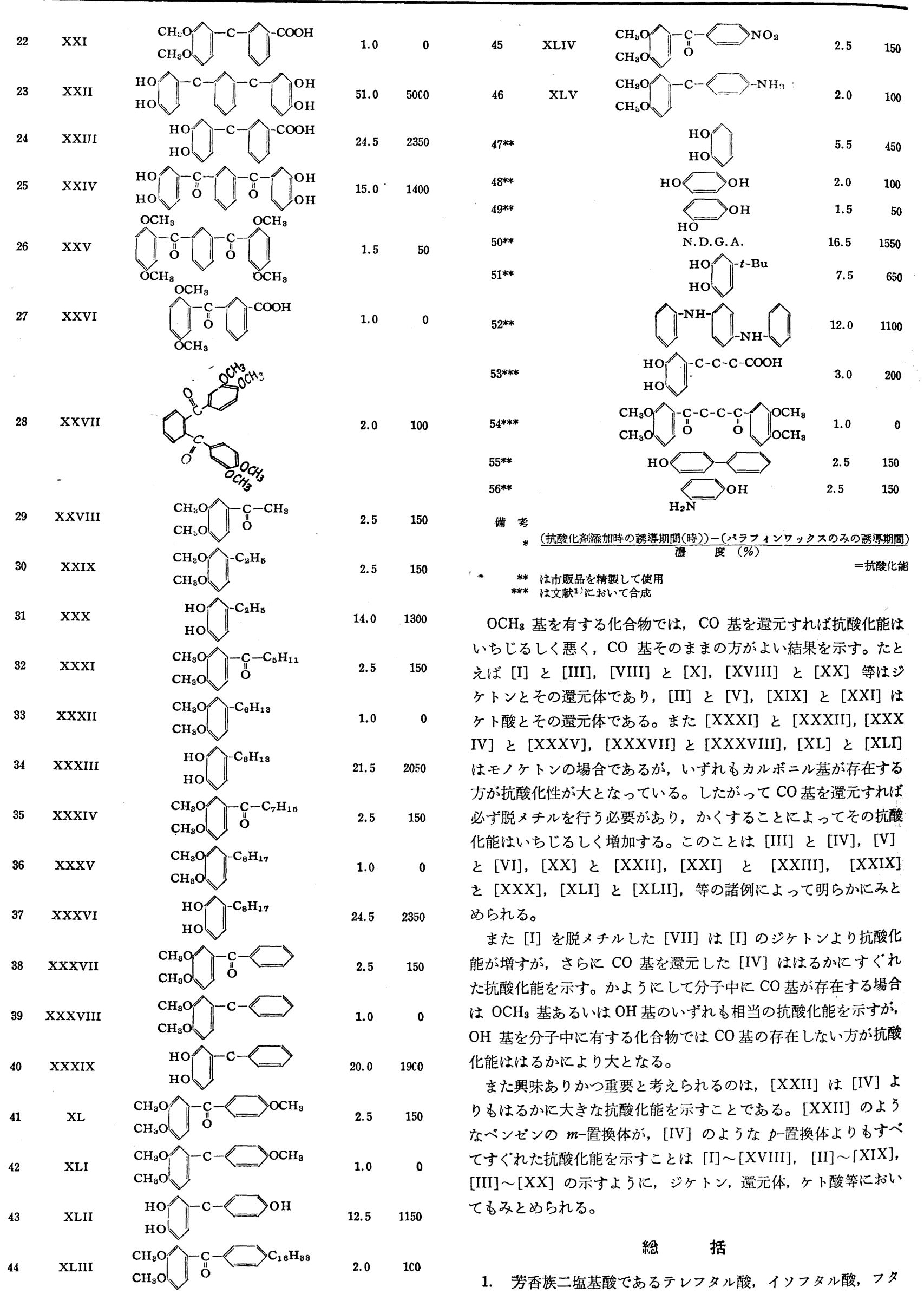


ル酸の酸クロリドと，ピロカテコール，ヒドロキノン等のジメチ ルエーテルとから, 無水塩化アルミニウムを触媒とするフリーデ ル・クラフッ反応によりジケトンを合成し, ウォルフ・キッスナ 一法により還元を行い, のち脱メチルして, 1, 4-ビスー (3, 4-ジオ キシベンジル)ーベンゼン, 1, 4-ビスー(2,5-ジオキシベンジル)ーベ ンゼン, 1,3-ビス (3,4-ジオキシベンジル)-ペンゼン, 4-(3,4-ジ オキシベンジル)-安息香酸, 3-(3, 4-ジオキシベンジル)-安息香 酸等をえた。また各合成過程において中間体および誘導体とし て，若干の新化合物を合成した。

2. 炭素数，2，6，8，ベンジル基， $-\mathrm{C}-\square \mathrm{OH}$ 基)。

3. 合成によってえた約 40 種類の化合物について，パラフィ
ンワックスに対する抗酸化性を測定した。その結果化学構造と抗 酸化能との関連性について，若干の知見をうることができた。

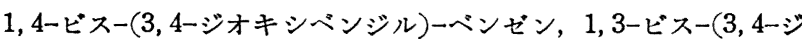

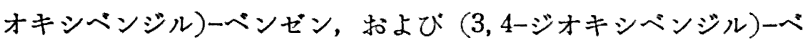
ンゼン, 3-(3,4-ジオキシベンジル)-安息香酸等は NDGA より はるかにすぐれた抗酸化能を示し，その合成の収率も比較的良好 で，工業的見地より実用性を有するきわめて優秀な抗酸化剤と考 えられる。

(昭和 31 年 4 月 3 日, 日化第 9 年会講演)

本研究に使用したピロカテコールは宇部興産株式会社より，テ レフタル酸は日本触媒株式会社よりそれぞれ寄贈を5けたるので 両社に対して厚く御礼申上げます。また実験の一部を担当された 卒業論文学生高川静君の御協力を感謝します。

\section{脂肪族アルコールのクロルメチル化によるクロルメチルアルキルエーテルの合成}

（昭 和 31 年 9 月 22 日受理)

\section{島村 恒夫・山下 雄 也*}

\section{緒䇾}

脂肪族高叙アルコールのクロルメチル化物に，ピリジン等の第 3 級アミンを作用してえられる長鎖アルキルオキシメチルピリジ ニウムクロリドは, カチオン活性凮, Velan 系 (ICI) 撥水郕お よび䋐維の柔軟仕上鼡として, また低級アルコールのクロルメチ ル化物は他のハロゲン化アルキルにくらべ反応性に富んでいるの で，有機合成の中間体として重要である。しかしこのクロルメチ ルアルキルェーテルに関する報告は非常に少なく，その多くは特 許になっている。

長鎖アルキルオキシメチルピリジニウムクロリドは ICI の特 許1)になっていて，その合成法は，七チルアルコール，パラホル ムアルデヒド扣よびピリジン等のアミン類の混合物に亜硫酸ガス を 80〜90ㄷ で通じ，分離したセチルオキシメチルピリジニウム サルファイトにシュウ酸を加え, 85 90 $90^{\circ} \mathrm{C}$ に加熱してセチルオ キシメチルピリジニウムシュウ酸塩をえている。

また Bock, Houk (Röhm \& Hass) などによれば2), ラウリ ルアルコール，パラホルムアルデヒドおよびトルェンの混合物 に， $5^{\circ} \mathrm{C}$ 以下で塩酸ガスを飽和させクロルメチルラウリルエーテ ルをえた特許があるが，いずれる詳細は不明である。したがっ て著者らはクロルメチルアルキルエーテルを $\mathrm{CH}_{3}:\left(\mathrm{CH}_{3}\right)_{2} \mathrm{CH}$, $\mathrm{C}_{4} \mathrm{H}_{9--}, \mathrm{C}_{8} \mathrm{H}_{17-}, \mathrm{C}_{12} \mathrm{H}_{25}, \mathrm{C}_{16} \mathrm{H}_{35}$ ，および $\mathrm{ClCH}_{2} \mathrm{CH}_{2}$ の各 1 価 アルコールにつき，ホルマリンまたはパラホルムアルデヒドと塩 酸ガスを反応させ，いわゆるクロルメチル化反応により合成し， 反応条件および生成物の性質等につき二，三検討し，さらに前記 1 価アルコールと異なり, 現在まで文献を見ない2 価アルコー ル, すなわちエチレングリュールのジクロルメチルエーテルの合 成に成功したので報告する。

* 工学院大学：東京都新宿区.

1) H. A. Piggott (ICI). U. S. P. 2, 146, 406 (1939); A. W. Baldwin, H. A. Piggott (ICI). U. S. P. 2, 147, 811(1939).

2) U.S. P. 2, 084, 125 (1937); 2, 204, 653 (1940).

\section{実験および結果の考察}

\section{1 価アルコールのクロルメチル化}

アルコール，ホルマリンまたはパラホルムアルデヒドの各 1

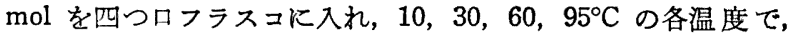
はげしくかきまぜながら乾燥塩酸ガスを吹込み飽和させる。5～6 時間後にクロルメチルェーテルは上層に分離し, 塩酸ガスが吸収 されなくなるが，さらに 4〜5 時間反応を続ける。反応液は分液 漏斗に移し，廃酸液を除きクロルメチルエーテルは塩化カルシウ ムで脱水後蒸留する。すし反応後 2 層に分離しない場合は, 塩化 カルシウムで塩析する。

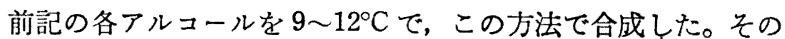
結果は第 1 表に示した。生成したクロルメチルエーテルの沸点は いずれも，もとのアルコールより $20 〜 30^{\circ} \mathrm{C}$ 高く，収率は $80 \%$ 前後である。 $\mathrm{CH}_{3}$ ， $\left(\mathrm{CH}_{3}\right)_{2} \mathrm{CH}-, \mathrm{C}_{4} \mathrm{H}_{9}-, \mathrm{C}_{8} \mathrm{H}_{17}$ ， および $\mathrm{ClCH}_{2}$. $\mathrm{CH}_{2}$-のアルコールはいずれも溶媒なしで進行するが, $\mathrm{C}_{16} \mathrm{H}_{33} \mathrm{OH}$ は溶媒に石油エーテル，ジクロルエチレン，ヘンゼン等の不活性 物を用いることが反応を容易にする。アルコール, “ルマリンの 反応割合を各 $1 \mathrm{~mol}$ および種々变えて見たが，いずれも収率は 同じでまたホルマリンのかわりにパラホルムアルデヒドを用い たが同様の結果がえられた。

触媒に塩化亜鉛を用いることは反応を早め, ブタノールのパラ ホルムアルデヒドによる 5 時間の反応で収率を $62 \%$ から $80 \%$ に高めることができた。

\section{エチレングリコール（2 価アルコール）のクロルメチル化}

上記はいずれも 1 価のアルコールであるが，著者らは 2 価のア ルコール，すなわちエチレングリコールについてクロルメチル化 反応を行ったところ，ジクロルメチルエーテルをえた。 $\mathrm{HOCH}_{2} \mathrm{CH}_{2} \mathrm{OH}+\left(\mathrm{CH}_{2} \mathrm{O}\right)_{n}+\mathrm{HCl} \longrightarrow$ $\mathrm{ClCH}_{2} \mathrm{OCH}_{2} \mathrm{CH}_{2} \mathrm{OCH}_{2} \mathrm{Cl}$

エチレングリコール $1 \mathrm{~mol}$, パラホルムアルデヒド $2 \mathrm{~mol}$ をフ ラスコに入れ（触媒に塩化亜鉛を用いても可），乾燥塩酸ガスを 